\title{
土壌表層の攪乱場所を特定するための初磁化率の応用
}

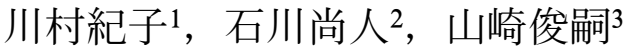 \\ 1海上保安庁海上保安大学校 基礎教育講座 \\ 干737-8512 広島県呉市若葉町 5 番 1 号 \\ 2富山大学都市デザイン学部 地球シムテム科学科 \\ 干930-8555 富山県富山市五福3190 \\ 3 東京大学大気海洋研究所 海洋底科学部門 \\ 干277-8564 千葉県柏市柏の葉 5 丁目 1 番 5 号
}

\section{Application of magnetic susceptibility for the identification of disturbed soil surfaces}

\author{
Noriko Kawamura ${ }^{1}$, Naoto Ishikawa ${ }^{2}$ and Toshitsugu Yamazaki ${ }^{3}$ \\ ${ }^{1}$ Department of Liberal Arts, Japan Coast Guard Academy \\ 5-1 Wakaba-cho Kure-shi, Hiroshima 737-8512 Japan \\ ${ }^{2}$ Department of Earth System Sciences, Faculty of Sustainable Design, University of Toyama \\ 3190 Gofuku, Toyama 930-8555, Japan \\ ${ }^{3}$ Atmosphere and Ocean Research Institute, The University of Tokyo \\ 5-1-5, Kashiwanoha, Kashiwa-shi, Chiba 277-8564 Japan
}

(Received 11 May 2021; accepted 15 October 2021;

Published online 14 December 2021 in J-STAGE DOI: 10.3408/jafst.819)

We tested magnetic susceptibility (MS) as a forensic search tool to detect the disturbed area on soil surface. A 250-cm-long survey line was assessed on the campus ground of the Japan Coast Guard Academy in this study. A hole of $10 \mathrm{~cm}$ length $\times 20 \mathrm{~cm}$ width $\times 7 \mathrm{~cm}$ depth was dug on the survey line and backfilled using soil mixture. MS was measured using a magnetometer at $10 \mathrm{~cm}$ intervals along the line, and the peaks were observed in the disturbed area. A soil core sample of $7 \mathrm{~cm}$ in length was collected near the line. The grain size of the core was classified as silty sand with granite granules that may have originated from the parent rock. The ratio of granule composition increased with soil depth. MS, anhysteretic remanent magnetization (ARM), isothermal remanent magnetization (IRM), and magnetic hysteresis curves were measured using the dried soil samples. The values indicated a peak at the $7 \mathrm{~cm}$ depth, where large number of granite granules were present. This implied that MS, ARM, and IRM peaks were caused by the granite granules. The granules were moved to the disturbed soil surface and may have contributed to high MS values. Thermomagnetic analyses revealed the presence of magnetite, maghemite, and hematite in the soil. The magnetic hysteresis parameters showed that the magnetic 
grain size also increased with burial depth and was consistent with the observed grain size distribution. The values of the disturbed area were located at the center of all the samples on a Day plot, implying that the grains of all soil layers were contained in the disturbed area. The MS peak could be recognized one year later although the hole was covered by weeds. The location of the disturbed area could be detected using a MS survey.

\section{Key words: Soil, Magnetic susceptibility, Disturbed area}

\section{緒 言}

土䱋は事件や事故の鑑定資料として採取され ${ }^{1)}$, 異同識別を目的として顕微鏡の観察, 粒度分析や化

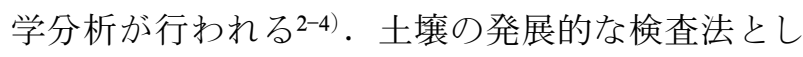
ては，土壌細菌のDNA に着目した例などが報告さ

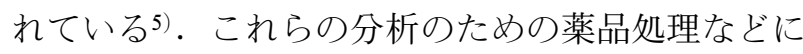
よって試料の残存量は減少する。よって，できるだ け証拠品としての試料量を残すために，非破壊で分 析可能な手法の提案が望まれる. また我が国の法地 質学では, 鑑定資料としての土壤の鑑定方法の研究 がほとんどであり 1-3), 犯罪の現場での土壌の簡便 な検査方法に関しての研究例が少ない.

土壤が犯罪などによって攪乱され, 証拠品が秘匿 されている場合, これらの場所を推定するために, 地中レーダーや音波探查, 磁気探查などが実施され てきた ${ }^{6,7)}$. 特に磁気探査のなかでも初磁化率の測 定は, 非破壊で迅速かつ簡便に広範囲で実施が可能 であり, 様々な捜査に適用されてきた. 土壌の初磁 化率の值は, 土堹に含まれている強磁性鉱物, 磁鉄 鉱 $\left(\mathrm{Fe}_{3} \mathrm{O}_{4}\right)$, 磁赤鉄鉱 $\left(\gamma \mathrm{Fe}_{2} \mathrm{O}_{3}\right)$, 赤鉄鉱 $\left(\alpha \mathrm{Fe}_{2} \mathrm{O}_{3}\right)$ や針鉄鉱 $(\alpha \mathrm{FeOOH})$ の量や種類を反映し, その 地域の母岩や気象条件などによって変化する ${ }^{8)}$.さ らにスコップやナイフといった強い磁化を持つ鉄製 品が土壤に秘匿されているとき, 埋没深度が浅い場 合は, 少量であっても初磁化率の值は周囲と比較し て高く示されるため,これらの秘匿場所の特定が可 能である ${ }^{8,9)}$. 工場や発電所周辺の土壤には, 煙突 から排出された金属類が多く含をれるために初磁化 率も周囲より高い值を示す 10 . よって土䁃の初磁化 率測定は, 污染源の特定だけでなく, 環境モニタリ ングにも応用されている. また土壤中に遺体が埋 まっているとき, 動物の血液中にへモグロビンとし
て含まれる多量の鉄が酸化し，磁鉄鉱や磁赤鉄鉱が 生成されるので, 周囲の初磁化率と比較して高い初 磁化率を示す事例が報告されている11,12).

初磁化率の測定によって土壌表層が覺乱された場 所の推定を試みた研究例は, Pringle et al. (2015) で報告されている。この研究では土壌表面の面積20 $\times 20 \mathrm{~cm}$, 深さ $10 \mathrm{~cm}$ の土壌を切り取り, これを水 平方向に $180^{\circ}$ 回転させて静置し, 初磁化率を測定し た. その結果, 切り取った場所の初磁化率は周囲の 值よりも相対的に高い状態が 1 年間継続した ${ }^{8)}$. こ れは土壌中の強磁性鉱物が土壌表面に露出したこと で初磁化率が高くなり 1 年間にわたってピークとし て現れたためと考えられる。したがって初磁化率の 測定は， 1 年間にわたって土壤表層が覺乱された場 所の位置の推定に有用であることが示唆された。も し我が国の土壌においても，この初磁化率の測定に よって攪乱場所の検出が可能であることが示されれ ば，秘匿物の捜索に役立つと考えられる．初磁化率 の測定は, 土䁃表面を化学変化させずに非破壊で実 施が可能である。初磁化率測定と同様に携帯型の蛍 光 $\mathrm{X}$ 線装置を用いた分析は, 文化財の調查などで も用いられており, 土䁃表面をほとんど化学変化さ せることなく実施可能である.しかし，日本での土 壤の初磁化率の測定例は少なく, 基礎的なデータが 不足している状態であり，秘匿物の捜査で有用性を 確認した研究報告はない。そこで本研究は, 日本で 秘匿物の捜索が行われることの多い雑木林の土壃を 研究対象とし, 秘匿場所の土壌の攪乱位置を特定す るために，初磁化率を測定し，その有用性を検証す ることを目的とした。

\section{材料および方法}

土壌表面の初磁化率の時間変化を把握するため 
に， $250 \mathrm{~cm}$ の観測線を設定して 1 年間にわたり， 月一回の測定をした。携帯型の蛍光 X 線装置を用 いて攪乱場所の土壌表面の化学分析を行った。 また 土壤の柱状試料から鉛直方向の強磁性鉱物の分布を 調べた。

\section{1. 土壊試料}

本研究では, 広島県点市若葉町にある海上保安大 学校内の雑木林の土壌を対象とした（Fig. 1a and b)。ここには, 明治22年から日本海軍の弾薬製造 所である呉海軍工廠火工部があり，昭和 27 年 4 月 (西暦1952年) に海上保安大学校が設立されてから 土壤が形成された。この雑木林には普段, 人の出入 りはほとんぞ無いが，例年 8 月上旬には除草され る.

本研究対象の雑木林の土壌から2018年 5 月14日に ソイルサンプラー（株式会社アイシス社製,

AMP301）を用いて直径 $2.2 \mathrm{~cm}$, 長さ約 $7 \mathrm{~cm}$ の柱 状試料を採取し，肉眼および偏光顕微鏡での観察を 行った. 深度 $0 \sim 2 \mathrm{~cm}$ にかけて黒褐色の腐葉土が 分布し, 約 2 7 cm は母岩由来と考えられる花崗 岩の砂碟を含む暗灰黄色シルトが認められた。土壌 の岩石部分は主に砂サイズの粒子から成っており， 平均粒径は深度方向に増加する傾向が見られた。採 取土壌は褐色森林土に分類され, 深度 $0 \sim 2 \mathrm{~cm}$ ま では $\mathrm{O}$ 層, 約 2〜 $7 \mathrm{~cm}$ は A 層と識別される（Fig. $3 \mathrm{a})^{13)}$. この柱状試料の $\mathrm{O}_{1}$ 層の深度 $0 \sim 2 \mathrm{~cm} \quad(2.87$ $\mathrm{g}), \mathrm{A} 1$ 層の $3 \sim 5 \mathrm{~cm}(5.73 \mathrm{~g}), \mathrm{A} 2$ 層の $6 \sim 7 \mathrm{~cm}$ $(7.22 \mathrm{~g})$ の土壤試料をサンプリングして, 乾燥さ せてチャック付きポリエチレン袋（ユニパック：生 産日本製）中で保管した。また $\mathrm{O}$ 層， $\mathrm{A}_{1}$ 層と $\mathrm{A}_{2}$ 層の乾燥させた土壤試料から同量を取り出して混合 した試料は，後述する磁気測定に使用した.

また同日に柱状試料を採取した地点から約 $50 \mathrm{~cm}$ 離れた場所に, 定期的な初磁化率測定を行う観測線 （長さ：250 cm）を設けた。観測線の表層は均質な 腐植土に覆われていて, 初磁化率に大きく寄与する ような岩石片などは認められなかった。観測線の $110 \sim 120 \mathrm{~cm}$ に, 観測線に直交させて約 $10 \mathrm{~cm} \times 20$ $\mathrm{cm} \times$ 深さ $7 \mathrm{~cm}$ の長方形の穴を新品のステンレス製 のスコップを使用して2018年5月21日に掘った (Fig. 1c and d). 穴の断面の観察を行ったところ深

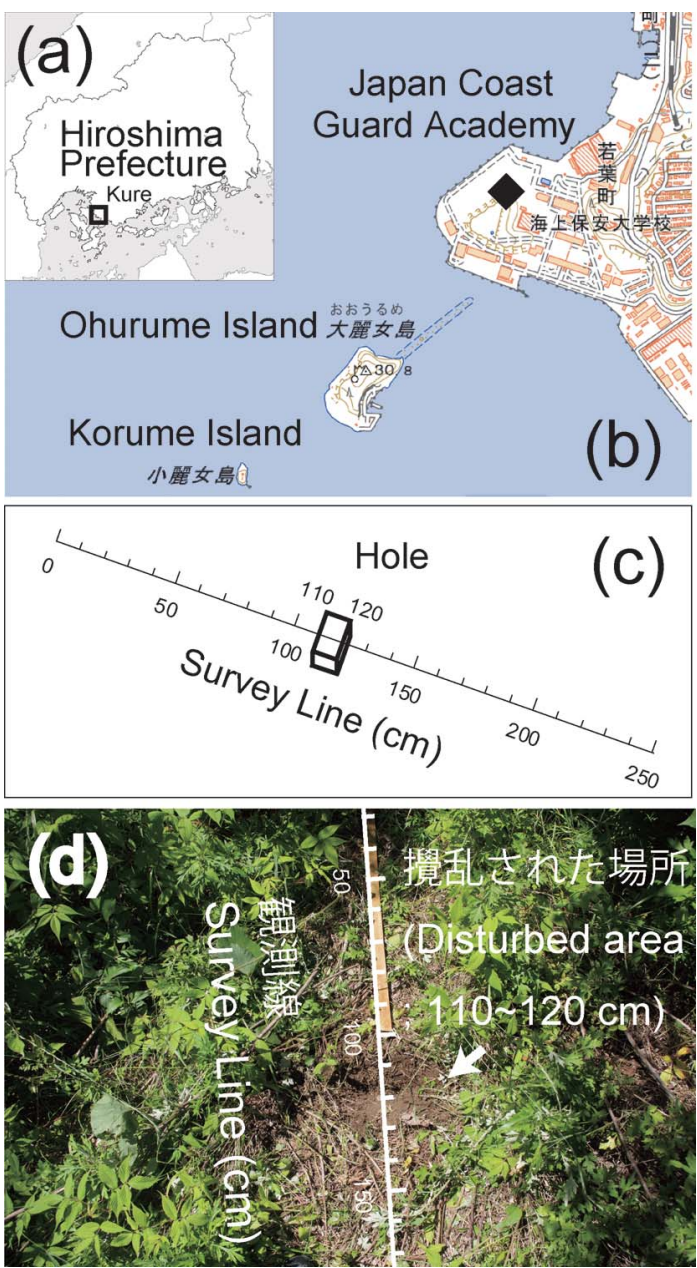

Fig. 1 (a) A white square indicates the study area in Hiroshima Prefecture; (b) the location map of this study area is modified using the e-map published by the Geospatial Information Authority of Japan (https://maps.gsi.go.jp/) - the black diamond shows the location of magnetic susceptibility measurements; (c) a diagram shows the $250-\mathrm{cm}$ length survey line on the campus of the Japan Coast Guard Academy - a hole of 10-cm length $\times 20$-cm width $\times 7$-cm depth was dug on the survey line and backfilled using the soil mixture; (d) a photograph shows the survey line near a hole.

度約 $0 \sim 2 \mathrm{~cm}$ には腐葉土の層, 約 $2 \sim 7 \mathrm{~cm}$ には花 崗岩の砂䃇を含むシルトの層があり, 柱状試料の採 取地点と同様の層相であった. 観察後に土䁃の上下 の層を混ぜて埋め戻し, 土壤表層と深度数センチ メートルの土壤が混合し, 攪乱された状態にした。 
Table 1 Sampling date, temperature, precipitation ${ }^{22)}$, and magnetic susceptibility (MS). SD means that the data standard deviation. Shading denotes that the survey line was covered with weeds and the data for Fig. $2 b \sim$ $2 \mathrm{~d}$.

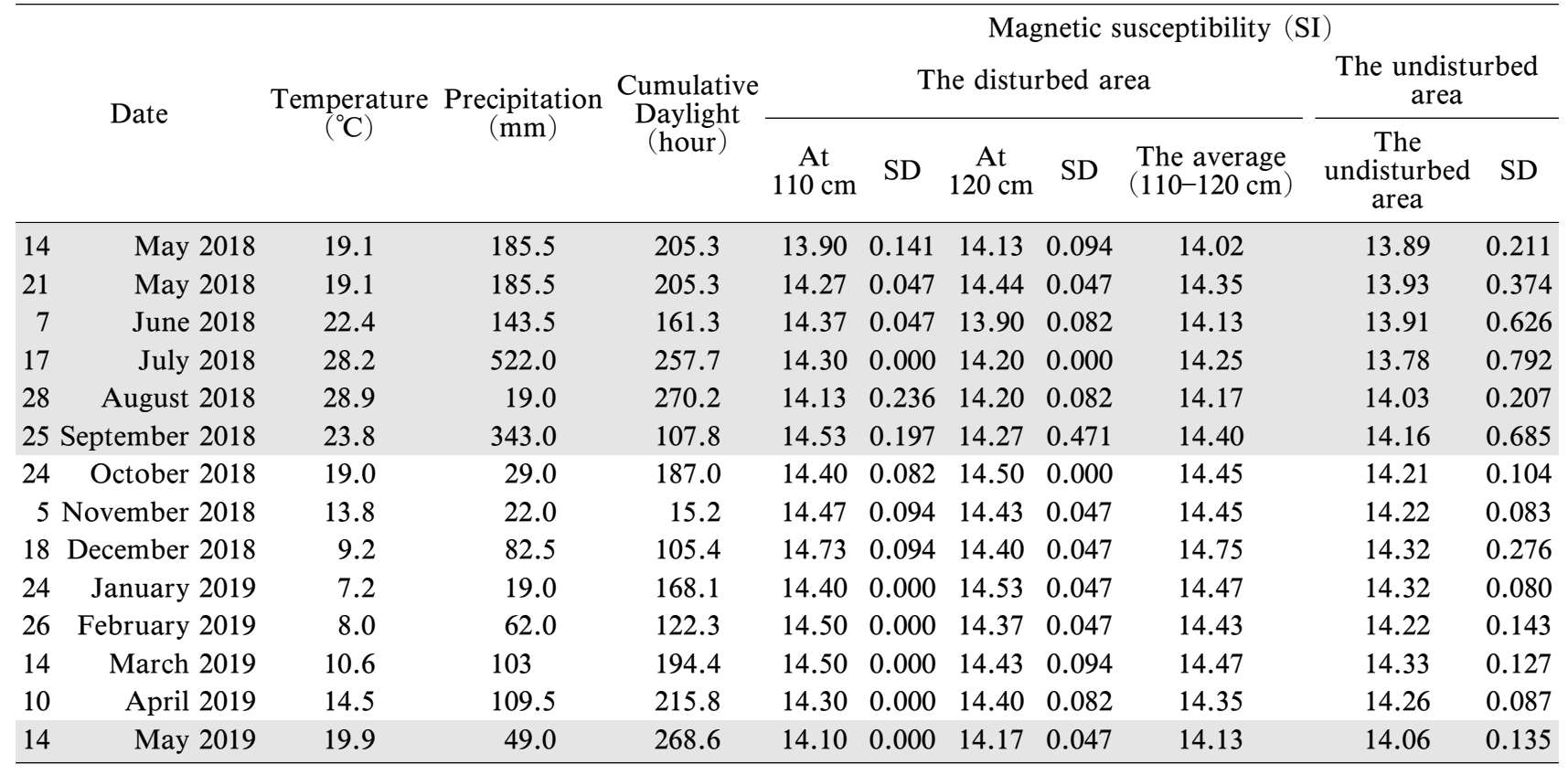

攪乱された場所の深度 $0 \sim 1 \mathrm{~cm}$ から混合土䁃を採 取して，乾燥させて磁気測定に使用した.

攪乱してから 2 か月後の2018年 7 月以降は, 雑草 により覆われてしまい攪乱された位置を目視で確認 することはできなかった。観測線の表面は，2018年 8 月上旬には人が観測線上に立ち入り, 草刈り機に よって除草されたが2018年 5９月にかけて雑草に 覆われていた（Table 1).

\section{2. 方法}

\section{2-1. 土壊表面の初磁化率}

初磁化率の測定には, 産業技術総合研究所が所有 している携帯型磁化率計（ZH instruments 社製,

SM-30）を用いて観測線上 $10 \mathrm{~cm}$ ごとに土壤表面の 初磁化率の読反取りの值（SI）を得た。初磁化率は 土壤表面から $2 \mathrm{~cm}$ の高さに保ち, 1 つの観測点ご とに 3 回の測定を行い, 平均值を算出した。この測 定は，2018年 5 月は14日に覺乱前，21日に覺乱後の 最初の測定を行い, その後は毎月一回, 晴天の日の 午前10時から11時半の間に実施した（Table 1). 観 測線 $110 \sim 120 \mathrm{~cm}$ のデータについては, $110 \mathrm{~cm}$ で は攪乱させた場所とそうでない場所の境界， 120 cm では攪乱させた場所内で測定した.

\section{2-2. 土壊の柱状試料の初磁化率と人工的残留磁化 の測定}

土壤試料に含をれる強磁性鉱物の相対量を推定す るために, 実験室において初磁化率の測定を行っ た. 土壤試料の初磁化率は Bartington 社製磁化率 計（MS2 System） で測定し, 試料の質量（0.2 $0.6 \mathrm{~g}$ ) 加ら単位質量あたりの初磁化率（ $\chi$ : 単位 $\mathrm{m}^{3} / \mathrm{kg}$ ) を算出した. 次に人工的に残留磁化を付し た. 交流消磁装置（夏原技研製）とソレノイドコイ ルを用いて, 試料に交流磁場 $100 \mathrm{mT}$ と直流磁場0.1 $\mathrm{mT}$ とを同時に付して非履歴残留磁化（Anhysteretic remanent magnetization: ARM) を獲得させ, 残 留磁化強度を測定した。パルスマグネタイザー (model MMPM-9, Magnetic Measurements 社製) を 用いて, キューブ試料の一軸方向に $2.5 \mathrm{~T}$ の直流磁 場を付加して等温残留磁化 (Isothermal remanent magnetization: IRM) を獲得させた. $2.5 \mathrm{~T}$ の時の IRM を飽和等温残留磁化 (Saturation IRM: SIRM) とする. SIRM の測定後, $2.5 \mathrm{~T}$ を付加した軸の反 対方向に0.3 T の磁場を付加し, その残留磁化を測 


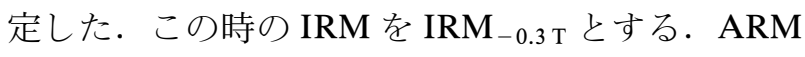
と IRM の測定には，スピナー磁力計（SMM-85, 夏原技研製）を用いた. 以下の Bloemendal et al. （1992）の計算式に基づいて，試料中の低保磁力の 強磁性鉱物や磁鉄鉱の比率を示す $\mathrm{S}$ 比 $\left(\mathrm{S}_{-0.3 \mathrm{~T}}\right)^{10)}$, 高保磁力の磁性鉱物量を反映する hard isothermal remanent magnetization (HIRM) を算出した ${ }^{14)}$.

$\mathrm{S}_{-0.3 \mathrm{~T}}=\left(1-\mathrm{IRM}_{-0.3 \mathrm{~T}} / \mathrm{SIRM}\right) / 2$

$\mathrm{HIRM}=\left(\mathrm{SIRM}+\mathrm{IRM}_{-0.3 \mathrm{~T}}\right) / 2$

以上の測定は，海上保安大学校で行った.

交番磁場勾配型磁力計（Micromag 2900-2C AGFM， Lake Shore 社製，京都大学所有）を用い て, 磁気ヒステリシスと残留保磁力 (Hcr) の測定 を行った．得られた磁気ヒステリシス測定の高磁場 （最大磁場の $70 \%$ 以上）の直線性を補正して，飽和 磁化強度 $(\mathrm{Ms})$, 飽和等温残留磁化強度（磁気ヒス テリシス曲線から求めた值を示すときは Mr を用い る), 保磁力 (coercivity: Hc) の值を求めた。 土塞 試料中の強磁性鉱物が不均質に分布して值がばらつ くことが予想されたため, 測定は 1 つの試料から 3 回分の試料取り分けて行い, 平均值を得た. 以上の 測定は, 京都大学で行った.

\section{2-3. 熱磁気測定}

土壤の柱状試料に含まれる強磁性鉱物の同定を目 的として，高温および低温での磁気測定を行った。 1 つの試料につき 1 回の測定を実施した。低温磁性 については2020年12月に高知大学海洋コア総合研究 センターの磁気特性測定装置（MPMS XL5, Quantum Designs 社製) を用いた. 数 $\mathrm{mg}$ の乾燥土壤試 料を約 $3 \times 3 \mathrm{~cm}$ のポリ塩化ビニリデン（サランラッ プ，旭化成製）で相包して，プラスチック製のサン プルフォルダーに入れて室温から $5 \mathrm{~K}$ まで無磁場中 で低下させ， $5 \mathrm{~K} て ゙ 2.5 \mathrm{~T}$ の磁場をかけ，IRM を獲 得させた。 その後に, 無磁場で $5 \mathrm{~K}$ から $300 \mathrm{~K}$ まで 昇温させて SIRM 強度の変化を測定した.

高温での磁気測定は, 熱磁気天秤（栄光電機製, 2019年までは京都大学所有, 以降は富山大学に移 動）を用いて，2018年 6 月に空気中でキュリー点の 推定を実施した。乾燥させた数百 $\mathrm{mg}$ の土壌試料を 石英カップに入れて, 強磁場をかけた状態で室温か ら $720{ }^{\circ} \mathrm{C}$ まで空気中で加熱し, その後に室温まで冷
却し，誘導磁化の変化を測定した．

\section{2-4. 土䁃に含まれる強磁性鉱物の観察}

土砂の鑑定においては, 粒子の形状から異同識別 を行うことを目的として走査型電子顕微鏡を用いた 粒子の観察が行われる場合がある2). 本研究では, 土壤試料の強磁性鉱物の基礎的なデータを得るため に, 電子顕微鏡による粒子の観察を行った. 強磁性 鉱物のうち磁鉄鉱は, 単位質量当たりの初磁化率の 值が粒子サイズ約 $20 \mathrm{~nm}$ 前後で最大值となる ${ }^{15)}$. 単 磁区の粒子の特徵を捉えるために東京大学大気海洋 研究所の透過型電子顕微鏡 (Transmission Electron Microscope: TEM, JEOL 社製, JEM-1400, 加速電 圧120 kV) での観察を実施した。攪乱された110〜 $120 \mathrm{~cm}$ の表層から採取した土壤試料 $1.00 \mathrm{~g}$ をコニ カルビーカーに入れて, $200 \mathrm{~mL}$ の超純水を加え, 水中にサマリウムコバルト磁石を用いて24時間放置 して試料中の強磁性鉱物を抽出した. 抽出によって 得られた強磁性鉱物は保存中に酸化による変質を防 ぐため, 観察の直前までエタノール中で保管した.

\section{2-5. 土壤表層の蛍光 $\mathbf{X}$ 線分析}

株式会社リガク所有の携帯型の蛍光 X 線 (X-ray Fluorescence: XRF) 分析装置機器 (Niton 携帯型 成分分析計 XL3 t950S, 鉱物 ·土壤 ·各種素材用) を用いて，土壤表面の元素分析をした. 2018年11月 7 日に，観測線上の $90 \mathrm{~cm}$ の攪乱されていない地点 および $115 \mathrm{~cm}$ の覺乱された地点の凹凸のある土䁃 表層において, 土壌測定モードによって空気中で直 径 $8 \mathrm{~mm}$ 円の範囲で $\mathrm{X}$ 線を 1 分照射して 1 回測定 した．分析した元素の範囲は $\mathrm{S} \sim \mathrm{Cl}, \mathrm{K} \sim \mathrm{Bi}$ であ り, 管電圧は最大 $50 \mathrm{kV}$ である. 元素の濃度はファ ンダメンタルパラメーター法により算出した。

\section{1. 土壌地表面の初磁化率}

\section{結 果}

測定結果を Fig. 2 に示す. Fig. 2a の黑色の丸印 は2018年 5 月14日の観測線上の初磁化率の平均值で あり，黒線は変動幅である。また灰色の三角印は， 2018年 5 月 21 日に観測線 $110 \sim 120 \mathrm{~cm}$ の覺乱させた 直後の初磁化率の平均值であり, 灰色線は変動幅で ある. 2018年 5 月 21 日の初磁化率は, 観測点 120 $\mathrm{cm}$ で最大值を示した。 観測点 $200 \sim 220 \mathrm{~cm}$ と250 

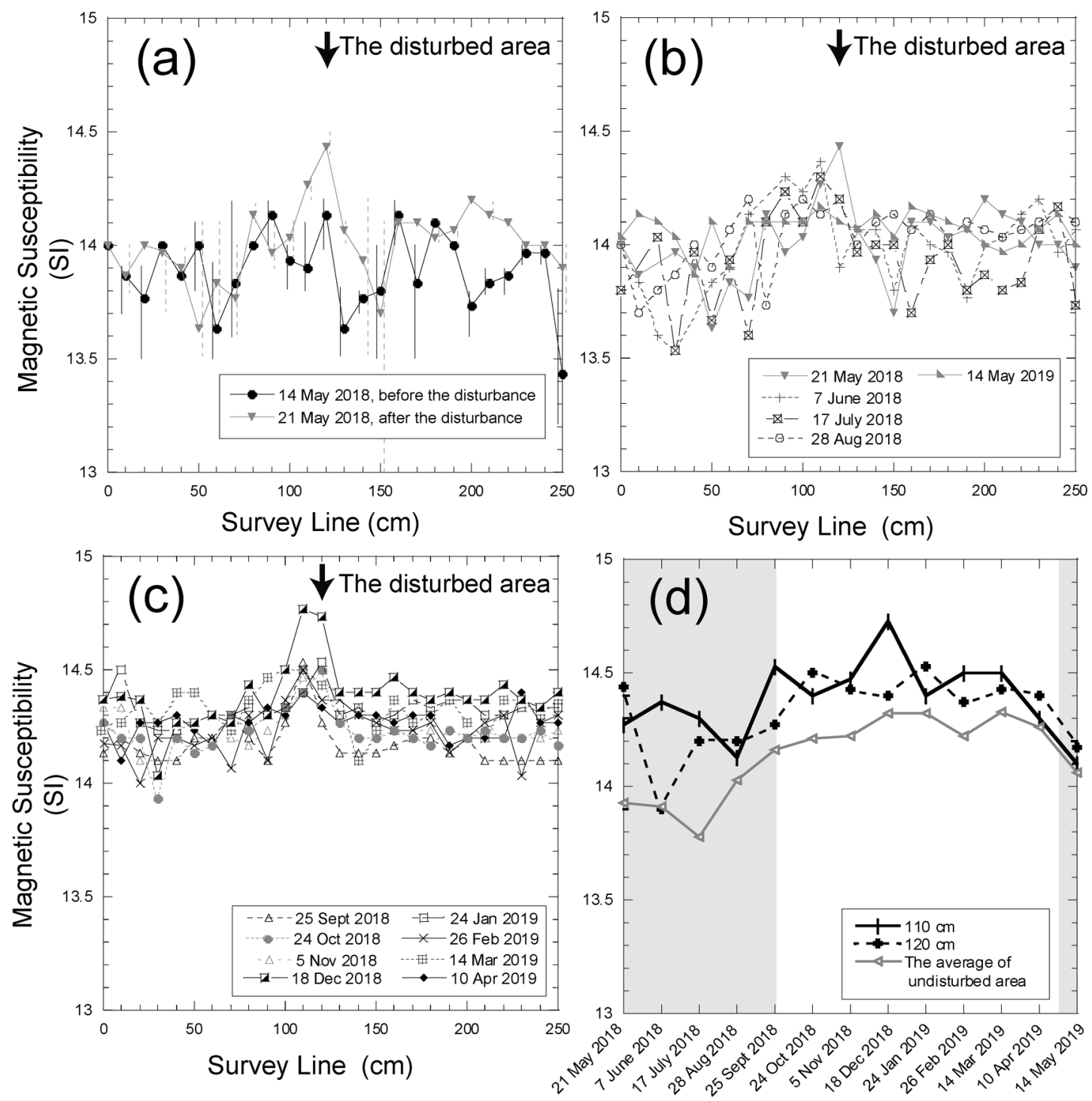

Fig. 2 (a)-(c) Magnetic susceptibility along the survey line - the arrows indicate the disturbed area where a hole was dug and backfilled using sandy soil (at $120 \mathrm{~cm}$ along the survey line); (a) the black circles indicate the average magnetic susceptibility (MS) before the disturbance - the gray triangles indicate MS after the disturbance and vertical lines show the range of variability before and after the disturbance; (b) average of the MS values from May to August 2018; (c) average of MS values from September 2018 to May 2019; and (d) MS values of the stations at $110 \mathrm{~cm}, 120 \mathrm{~cm}$, and the undisturbed area from May 2018 to May 2019 - the shading indicates that the survey line was covered with weeds at the time of measurement.

$\mathrm{cm}$ の值は，観測日の違いによる初磁化率の平均值 には変動幅を超えるほどの差があるが， 1 週間の時 間経過では，これらを除いて攪乱前と後で大きな変 化は認められなかった.

次に2018年 5 月 21 日から2019年 5 月 14日まで， 1 カ月抢きに測定した初磁化率の平均值を Fig. $2 \mathrm{~b}$ と $2 \mathrm{c}$ に示した. 攪乱された場所の110〜 $120 \mathrm{~cm}$ の初磁
化率の值は， $110 \mathrm{~cm}$ と $120 \mathrm{~cm}$ の少なくともいずれ か一方では，攪乱された場所以外の平均值よりも高 い值を示した。

Fig. $2 \mathrm{~d}$ は, 観測点の初磁化率の平均值をプロッ トしたものである. 月平均気温が低い月（2018年10 月～2019年 4 月）には，初磁化率は相対的に高い值 を示した（Fig. 2b〜2d; Table 1). 本研究結果と同 
様の傾向は Pringle et al. (2015) でも報告されてお り,これは初磁化率の温度依存性を表している8 ${ }^{8)}$.

観測月の平均気温，降水量，観測点 $110 \mathrm{~cm}$ と 120 $\mathrm{cm}$ の攪乱された場所の初磁化率を 3 回測定した值 の平均值と標準偏差, これらを除く観測点の平均值 と標準偏差を Table 1 に示す。 2018年 5～9 月は, 他の月に比べて平均降水量, 平均気温と日照時間が 多いために雑草が繁茂しやすい。地土㙥表面が除草 された 8 月を除いては雑草で覆われており, 標準偏 差は相対的に高かった。これは雑草が繁茂したため に土壤表面の凹凸が生じ, 初磁化率計との距離が一 定にならず，測定值のばらつきが大きくなった可能 性が考えられる．この期間以外の2018年10月～2019 年 4 月では雑草は枯れて土壤表面の凹凸は少なく, 攪乱された場所以外の初磁化率の標準偏差は比較的 小さい值を示した（Fig. 2c; Table 1).

以上のように温度依存性や土壌表面の凹凸によっ て初磁化率の值は変動するものの, 攪乱された場所 の $110 \sim 120 \mathrm{~cm}$ の初磁化率の值は, $110 \mathrm{~cm}$ と 120 $\mathrm{cm}$ の少なくともいずれか一方では，攪乱された場 所以外の平均值よりも高い值を示した（Fig. 2d; Table 1).

\section{2. 土壤の柱状試料の岩石磁気学的パラメータ}

柱状試料の初磁化率 $\chi$ と残留磁化の測定結果を Fig. $3 \mathrm{~b} \sim 3 \mathrm{f}$ に示す. $\chi$ は深度約 $2 \mathrm{~cm} の \mathrm{O}_{1}$ 層と $\mathrm{A}$ 層 ${ }_{1}$ との境界で最大值を示し, 深度 $5 \mathrm{~cm}$ までは下 方向に減少し, 母岩由来と考えられる砂碩が混入す る深度 $7 \mathrm{~cm}$ では, これ以外の層準よりも高い傾向 が認められた (Fig. 3b). ARMの值は, 深度 0〜5 $\mathrm{cm}$ までは下方向に減少し， $\chi$ と同様に深度 $7 \mathrm{~cm}$ で 最大值を示した (Fig. 3c). SIRMの值は, ARM の值と同様に深度 $3 \mathrm{~cm}$ までは深さと共に減少し, 深度 $4 \mathrm{~cm}$ でやや増加し, 深度 $7 \mathrm{~cm}$ でこれ以外の 層準よりも高い值になった (Fig. 3d). S 比は $\mathrm{O}_{1}$ 層では0.949であり，A層では $0.967 \sim 0.982$ の範囲 の值を示した（Fig. 3e）。これは保磁力の低い強磁 性鉱物の割合が A 層で高いことを示唆する。 HIRM は, SIRM と同様に深度 $4 \mathrm{~cm}$ で少し増加 し, 深度方向に值が減少した（Fig. 3f).

$\mathrm{O}_{1}$ 層, $\mathrm{A}_{1}$ 層と $\mathrm{A}_{2}$ 層の乾燥させた土壤試料を同 量混合した試料の岩石磁気学的パラメータを Fig. 3 のグラフの上部に星印（ネ）で示す。この星印で示 された $\chi_{\text {aver. }}$ と $\mathrm{ARM}_{\mathrm{aver}}$, $\mathrm{SIRM}_{\mathrm{aver}}$.の值は, 柱状試 料の深度 $1 \mathrm{~cm}$ と深度 $7 \mathrm{~cm}$ の值とほぼ同じであっ (a) Lithology

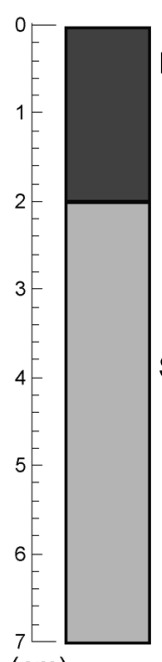

(cm) Base rock

(Granite) (b) $\mathrm{X}$

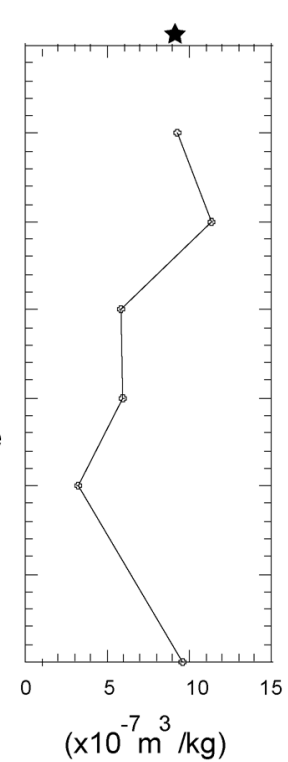

(c) ARM

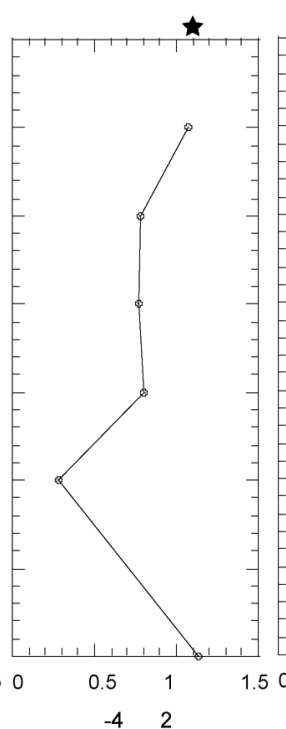

$\left(\times 10^{-4} \mathrm{Am}^{2} / \mathrm{kg}\right)$ (d) SIRM

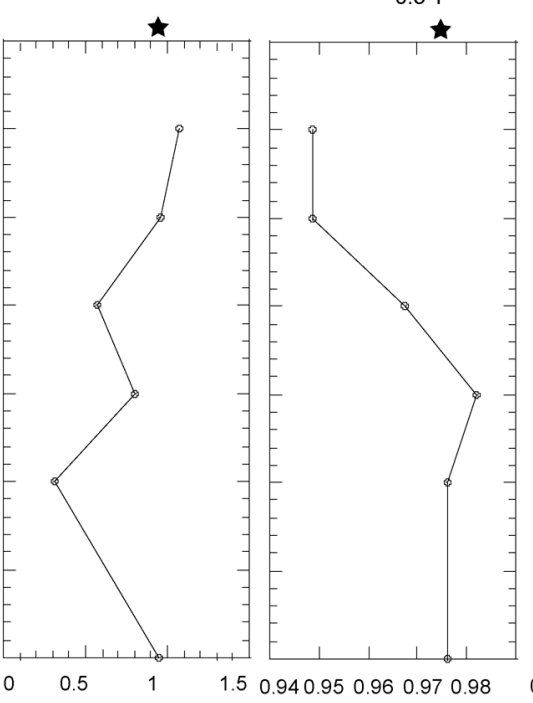

$\left(\times 10^{-2} \mathrm{Am}^{2} / \mathrm{kg}\right.$ ) (f) HIRM

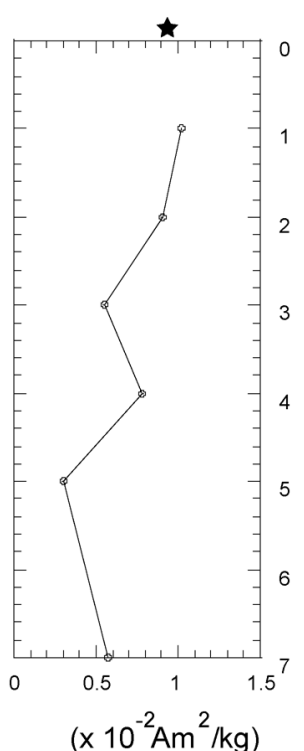

Fig. 3 (a) A soil core sample composed of two units - a black-brown "organic layer" consisting of fine silt lies at 0-2 cm and a dark olive-gray layer of silty sand lies at 2-7 cm; (b) $\chi$, (c) ARM, (d) IRM, and (e) S ratioa star indicates the average value of soils which are mixed with the 0-2-, 3-5-, and 6-7-cm samples. 
(a) $0-2 \mathrm{~cm}$

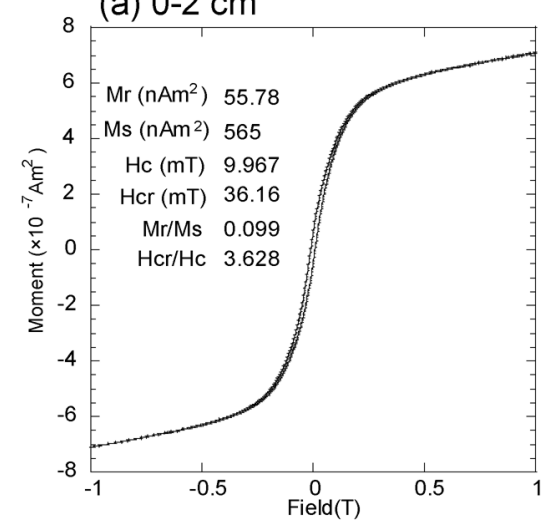

(c) $6-7 \mathrm{~cm}$

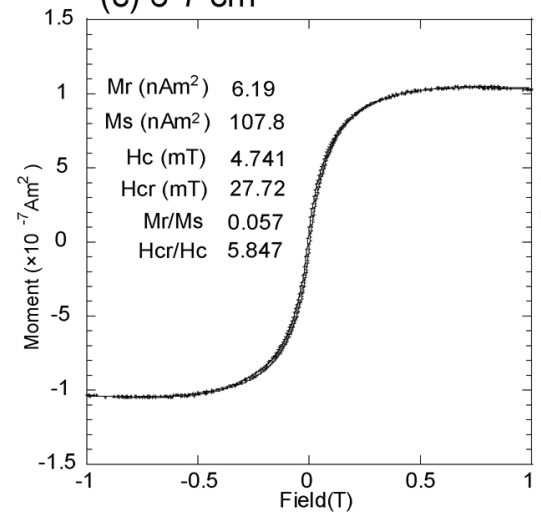

(b) $3-5 \mathrm{~cm}$

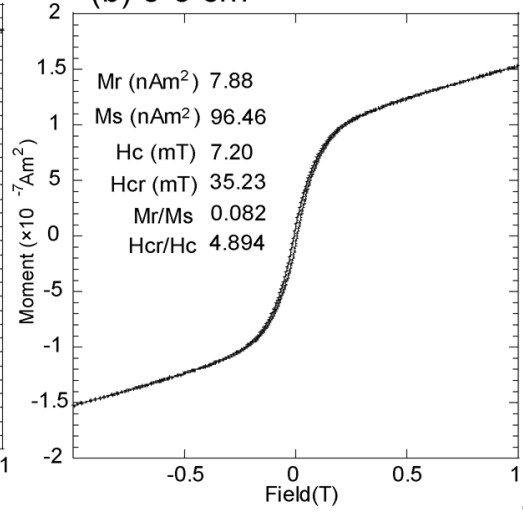

(d) The disturbed area

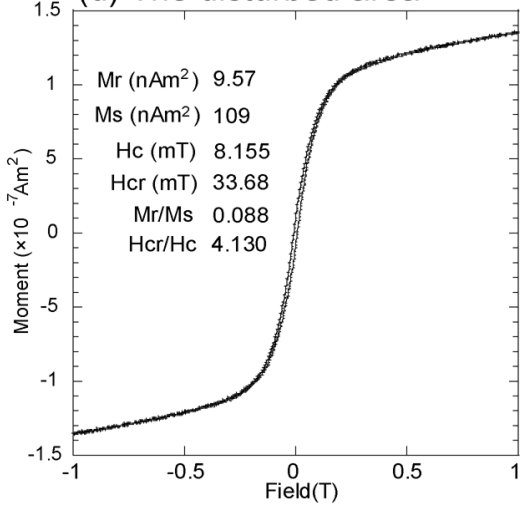

(e) Day plot

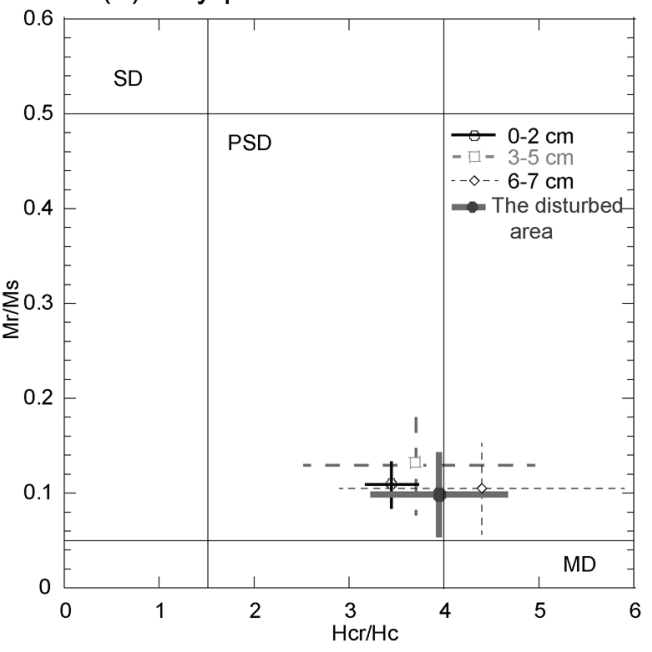

Fig. 4 (a)-(c) Magnetic hysteresis curves of the samples collected from the soil core; (d) magnetic hysteresis curves of the soil sample taken from the disturbed area; and (e) a Day plot ${ }^{16)}$ - single-domain (SD), pseudosingle-domain (PSD), and multi-domain (MD).

た. $\mathrm{S}$ 比は, $4 \mathrm{~cm}$ 以深の值と近い值であった。あ た $\mathrm{HIRM}_{\mathrm{aver}}$. は深度 $1 \mathrm{~cm}$ と近い值であった. 以上 から本研究では, $\mathrm{O}_{1}$ 層, $\mathrm{A}_{1}$ 層々 $\mathrm{A}_{2}$ 層の土壤が等 量ずつ混合された場合は, $\mathrm{S}$ 比の值が土㙥深部の值 に近いという結果が示された.

磁気ヒステリシス測定の結果を図 4 に示す。磁気 ヒステリシス曲線は土壤の柱状試料および観測線の $110 \sim 120 \mathrm{~cm}$ の攪乱場所の試料がフェリ磁性である ことを示した（Fig. 4a〜 4d）. Fig. 4eの Day plot に $\mathrm{Mr} / \mathrm{Ms}$ と $\mathrm{Hcr} / \mathrm{Hc}$ の值を示す. Day plot は, 磁 鉄鉱の粒径の推定を行うために考案されたもので, 左上の単磁区（Single domain: SD）側に位置する ほど磁鉄鉱の粒径は小さく, 右下の多磁区（Multi domain: MD）側になるほど粗いと解釈される16). 深度約 0〜 $2 \mathrm{~cm}$ では值のばらつきはあるものの, そのばらつきは他の深度の試料と比較して小さかっ
た. 砂䃯が散在する深度 $6 \sim 7 \mathrm{~cm}$ では, 試料の粒 子サイズは他の試料と比べて平均粒径が大きく, 測 定のために分割した試料も粒子サイズの不均質性が 大きかっために，ばらつきも大きかった． $\mathrm{O}_{1}$ 層と $\mathrm{A}_{1}$ 層の試料は磁鉄鉱の擬似単磁区 (Pseudo single domain: PSD）の範囲内に分布し, 深度約 $6 \sim 7 \mathrm{~cm}$ の試料はPSDの範囲からやや右側にプロットさ れ, 強磁性鉱物の平均粒径が比較的大きいことが示 された。肉眼観察では, 深度方向に土㙥中の岩片や 鉱物の平均粒径の増加が認められており, Day plot の結果と整合的であった。 また観測線の110〜120 $\mathrm{cm}$ の土䁃試料の平均值は PSD の範囲内であり, $\mathrm{Hcr} / \mathrm{Hc}$ の值の平均值は $\mathrm{O}_{1}$ 層, $\mathrm{A}_{1}$ 層と $\mathrm{A}_{2}$ 層の試 料の間に位置した。

\section{3. 土壤の磁化を担う強磁性鉱物種}

柱状試料と攪乱された土壌表層から採取した試料 

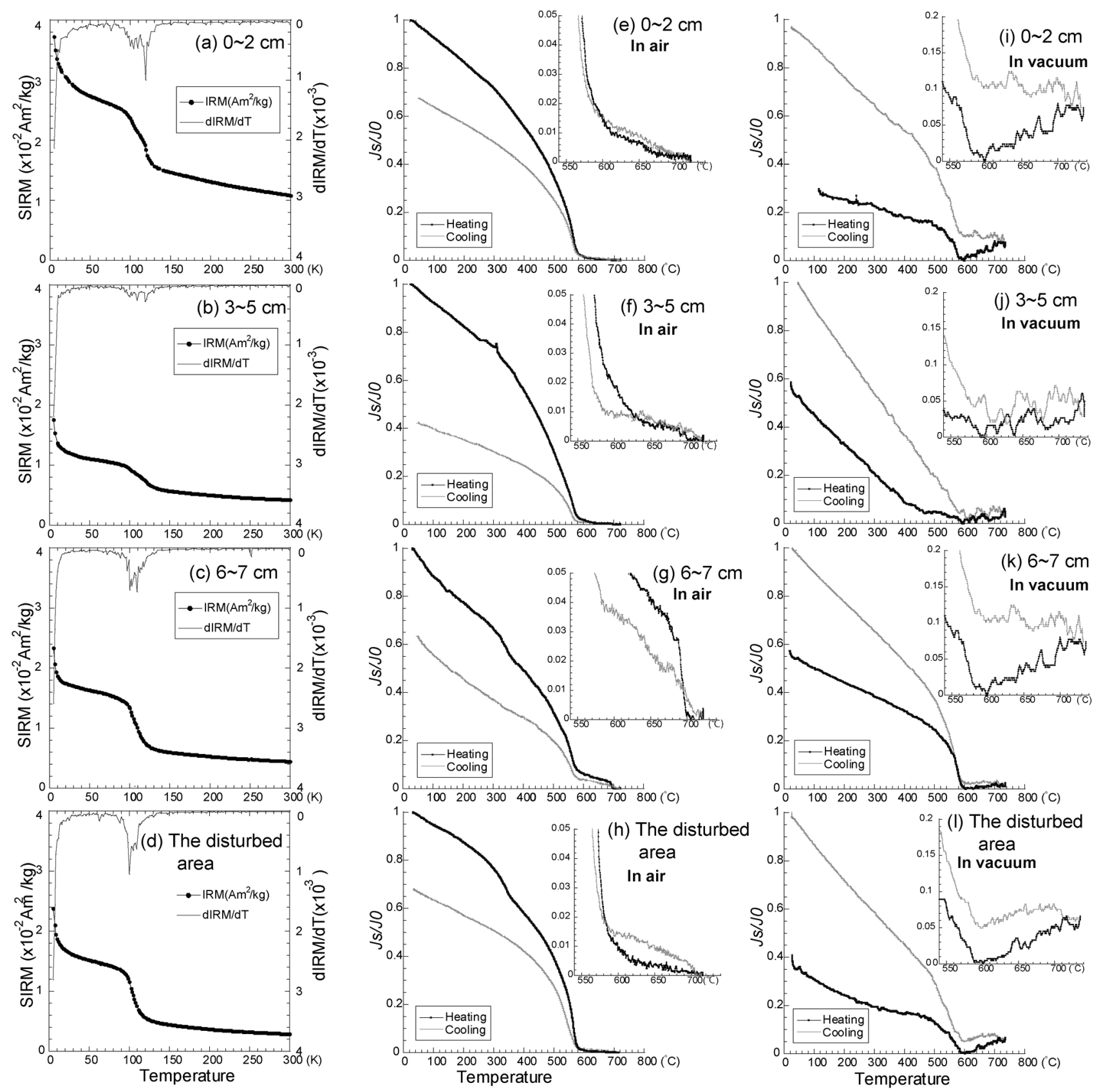

Fig. 5 (a)-(d) Thermal demagnetization curves for a low-temperature saturation isothermal remanent magnetization (SIRM) imposed at $5 \mathrm{~K}$ with a $2.5 \mathrm{~T}$ DC field - the black dots represent the SIRM intensity and gray lines correspond to dIRM/dT; (e)-(l) magnetization vs temperature curves - the measurements were conducted in air and vacuum and magnetization $(J S)$ values were normalized by magnetic susceptibility $(J O)$ when the measurement started at room temperature; the black curves indicate the values during heating, and gray curves show cooling curves; and the upper-right figures show the enlargement from $600{ }^{\circ} \mathrm{C}$ to $740{ }^{\circ} \mathrm{C}$ in air and from $570{ }^{\circ} \mathrm{C}$ to $740{ }^{\circ} \mathrm{C}$ in vacuum.

の熱磁気分析の結果を図 5 に示す。低温（5 Kから $300 \mathrm{~K} ）$ でのIRM の強度変化では全ての試料で磁 鉄鉱のフェルベー点 $(120 \mathrm{~K})$ 付近の $100 \mathrm{~K} \sim 120 \mathrm{~K}$
でIRM が減少したので, 磁鉄鉱が試料の磁化を担 う磁性鉱物であると判断できる（Fig. 5a〜 5d $)^{17)}$. 純度の高い磁鉄鉱ではフェルベー点がより明瞭であ 
るため,これらの試料の磁鉄鉱はチタン（Ti）が不 純物として含まれる, あるいは表面が酸化して磁赤 鉄鉱が存在している，もしくはこれら両方の可能性 が推定される18).

高温の磁気測定のうち, 空気中で加熱したときの 結果では, 全ての試料で磁鉄鉱のキュリ一温度であ る580 ${ }^{\circ} \mathrm{C}$ に抢いて誘導磁化が減少した（Fig. 5e〜 $5 \mathrm{~h})^{10)}$. 深度 $6 \sim 7 \mathrm{~cm}$ の試料には, 加熱中（Heating）の $320 \sim 360{ }^{\circ} \mathrm{C}$ 誘導磁化の減少と赤鉄鉱の キュリー温度である $680{ }^{\circ} \mathrm{C}$ 付近での減少が明膫に現 れた (Fig. $5 \mathrm{~g}$ ). 同様に攪乱された土壤表層から採 取した試料の加熱中の曲線でも，320 360 ${ }^{\circ} \mathrm{C}$ 付近 の誘導磁化の減少が見られた（Fig. $5 \mathrm{~h}) .680{ }^{\circ} \mathrm{C} の$ 付近の誘導磁化については, ノイズが多く不明瞭で あるものの, その值はやや減少した。

真空中での測定結果では, 同様に, 全ての試料で $580{ }^{\circ} \mathrm{C}$ におて誘導磁化が減少した（Fig. 5i〜 51). 特に腐植土などからなる $\mathrm{O}_{1}$ 層試料や攪乱された土 壤表層から採取した試料では，加熱中に $580{ }^{\circ} \mathrm{C} \sim$ $740{ }^{\circ} \mathrm{C} て ゙$ 磁化が増加した. 冷却時の誘導磁化強度は 加熱時より大きくなった．このことは加熱中に強磁 性鉱物が形成されたことを示唆する. 冷却時の曲線

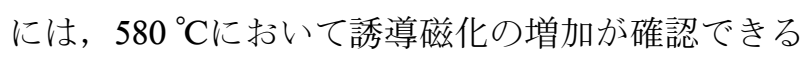
ため, 磁鉄鉱の存在が認められることから, 実験中 に有機物が還元剤となって磁鉄鉱が合成されたと推 定できる (Fig. 5i〜 51). 空気中で認められた320〜 $360^{\circ} \mathrm{C}$ 付近と $680^{\circ} \mathrm{C}$ 付近の誘導磁化の減少について は真空中での測定結果では認められなかった。した がって, 空気中で認められた誘導磁化強度の減少 は, $320 \sim 360{ }^{\circ} \mathrm{C} て ゙$ 磁赤鉄鉱が熱分解され, $680{ }^{\circ} \mathrm{C}$ 付 近で試料が酸化されて赤鉄鉱が生成されたためであ ると考えられる10).

TEM を用いて，観測線の110～120 cm の攪乱場 所の表層の土垬試料から抽出した強磁性鉱物の観察 を行った（Fig. 6). 約20〜50 nm の大きさの六角の 鉱物が複数認められた.これらの形態から, 赤鉄鉱 と推定される19).

\section{4. 土壤表層の元素分析}

土䗙表面の元素分析の結果を Table 2 に示した. 土壤や花崗岩の主要元素であるカリウム $(\mathrm{K})$, カ ルシウム $(\mathrm{Ca})$, 鉄 $(\mathrm{Fe})$ の濃度は, 高い值を示し
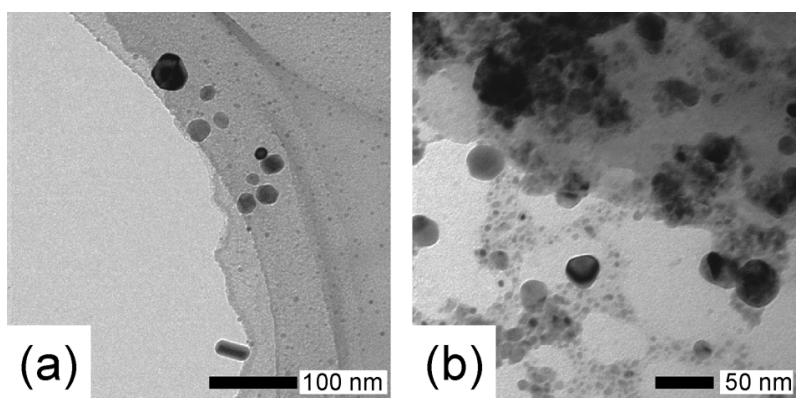

Fig. 6 Electron micrographs of the magnetic extracts - (a) the sample collected at 6-7-cm depth in the soil core and (b) soil sample from the disturbed area.

Table 2 Results of the X-ray fluorescence analysis on the disturbed and undisturbed soils. "n.d." means that the data was not determined.

\begin{tabular}{crr}
\hline Element & $\begin{array}{c}\text { At } 90 \mathrm{~cm} \text {, on the } \\
\text { undisturbed area } \\
(\mathrm{ppm})\end{array}$ & $\begin{array}{c}\text { At } 115 \mathrm{~cm} \text {, on the } \\
\text { disturbed area } \\
(\mathrm{ppm})\end{array}$ \\
\hline $\mathrm{S}$ & 881 & 794 \\
\hline $\mathrm{K}$ & 5246 & 1783 \\
\hline $\mathrm{Ca}$ & 114000 & 202000 \\
\hline $\mathrm{Sc}$ & 80 & 133 \\
\hline $\mathrm{Ti}$ & 413 & 87 \\
\hline $\mathrm{V}$ & 19 & 10 \\
\hline $\mathrm{Cr}$ & n.d. & 51 \\
\hline $\mathrm{Mn}$ & 295 & 155 \\
\hline $\mathrm{Fe}$ & 8931 & 5730 \\
\hline $\mathrm{Co}$ & n.d. & 131 \\
\hline $\mathrm{Cu}$ & 64 & 65 \\
\hline $\mathrm{Zn}$ & 84 & 97 \\
\hline $\mathrm{Rb}$ & 58 & 45 \\
\hline $\mathrm{Sr}$ & 42 & 63 \\
\hline $\mathrm{Zr}$ & 71 & 63 \\
\hline $\mathrm{Ba}$ & 233 & 90 \\
\hline $\mathrm{Pb}$ & 32 & 21 \\
\hline
\end{tabular}

た.これらの主要元素について土壌表層が攪乱され た場所 $(115 \mathrm{~cm})$ とそれ以外 $(90 \mathrm{~cm})$ の場所の值 を比較すると, 他の元素よりも大きな差が認められ た. 同様に Ti の值にも他の元素と比較して大きな 差が見られた。このように土畩表層の覺乱によって 
花崗岩の砂礫を含む $\mathrm{A}_{2}$ 層が土壤表面に現れたため に $\mathrm{K}, \mathrm{Ca}$ や $\mathrm{Fe}$ の濃度が高くなった可能性が示され た。

\section{考 察}

本研究では, 観測線上において攪乱させた場所と そうでない場所の境界である $110 \mathrm{~cm}$ と攪乱させた 場所内の $120 \mathrm{~cm}$ の初磁化率の平均值の両方, もし くはどちらか一方がこれら以外の観測点の平均值よ りも高い值を示す原因について，土壌の柱状試料の 岩石磁気学的パラメータやXRF 分析から考察する (Fig. 2d).これは攪乱による土壤中の空隙の大き さや単位体積あたりの空隙の割合の変化, もしくは 攪乱前後で土壌表層を構成する物質の違いを示唆す ると考えられる (Table 2). 柱状試料の岩石磁気学 的パラメータのうち $\chi, \mathrm{ARM}, \mathrm{SIRM}$ は, $\mathrm{O}_{1}$ 層の深 度 $1 \mathrm{~cm}$ と $\mathrm{A}_{2}$ 層の $7 \mathrm{~cm}$ で比較的高い值を示し, 攪 乱された $110 〜 120 \mathrm{~cm}$ と近い值を示した（Fig. 3b〜 $3 \mathrm{~d})$. 特に深度 $7 \mathrm{~cm}$ の試料では, 砂碟が散在し (Fig. 3a), 磁気的な粒径も相対的に大きい（Fig. 4e). $\mathrm{S}$ 比は深度 $4 \mathrm{~cm}$ 以深で $0.976 \sim 0.982$ であり, 攪乱された土壤表層では0.976であり，両者の試料 には保磁力の低い強磁性鉱物の割合が相対的に多い と考えられる (Fig. 3e). 同様に磁気的粒径を反映 するDay plotからも攪乱された場所の土壤が $\mathrm{O}_{1}$ 層, $\mathrm{A}_{1}$ 層と $\mathrm{A}_{2}$ 層の試料の值をカバーし, $\mathrm{Hcr} / \mathrm{Hc}$ の平均值は $\mathrm{A}_{1}$ 層と $\mathrm{A}_{2}$ 層の間に位置した。砂碩が 多く含まれる $\mathrm{A}_{2}$ 層の深度 $4 \mathrm{~cm}$ 以深の試料には, 他の層準と比べて保磁力が低く磁化強度の高い強磁 性鉱物が多く分布しており，これが攪乱によって土 壤表層に移動したことにより初磁化率のピークとし て現れたと考えられる．雑草に被われるなどの土㙋 表面の状態に依存して水平方向では初磁化率のピー クの位置は $10 \mathrm{~cm}$ ずれることはあるが， 1 年間にわ たってこのピークが維持される理由は, 磁鉄鉱と いった強磁性鉱物が土壌表面に移動してから，ほと んど変質を受けずに維持されたためと考えられる. 以上から，攪乱によって鉛直方向に土壤の物質が移 動して, 周囲と比較して主要元素の濃度差や初磁化 率の増加が認められた場合, 本研究と同じような母 岩と層準の土壌に拈いて 1 年以内であれば, 攪乱さ
れた場所を推定することが可能であると考えられ る.

次に Pringle et al. (2015) の結果と比較して議論 する. Pringle et al.（2015）は，攪乱された場所で の初磁化率は, 実験開始時と比較して 1 年後には約 7 割減少したと報告している. 彼らは初磁化率の減 少の原因について具体的に言及していないが，可能 性としては攪乱によって土壤中に埋没していた強い 磁性を持つ磁鉄鉱が空気中で酸化したり降水によっ て溶解して, 比較的磁化の弱い磁赤鉄鉱や赤鉄鉱, 水酸化鉄へ变化したと考えられる. 本研究結果で は，覺乱された110〜 $120 \mathrm{~cm}$ の土壌表面では，時間 経過に伴う初磁化率の減少は認められなかった (Fig. 2b 2d; Table 1). Pringle et al. (2015) の例と 比較すると, 彼らが実験したイギリスと日本とは, 気温や平均降水量などの気候区分, 土畩の種類や含 有する強磁性鉱物の量や粒径形, 種類が異なると考 えられる. 本研究との大きな相違としては, 実験方 法と土壌の違いが挙げられる. Pringle et al. (2015) では, 土壤表面の面積 $20 \times 20 \mathrm{~cm}$, 深さ $10 \mathrm{~cm}$ の土 壤を切り取り, これを水平方向に $180^{\circ}$ 回転させて静 置させているのに対して, 本研究では攪乱させて土 壤表層に砂碟を露出させている. 本研究地域の母岩 は花崗岩であり, 花崗岩には包有物として磁鉄鉱が 含まれている場合が多い20)，これらの由来の砂礫の 包有物にも磁鉄鉱が含まれる可能性は十分にあると 考えられる. 包有物は, 周辺の岩石や鉱物に被われ ているために降水などでは溶解せず， 1 年間という 時間では, ほとんど化学変化が起こっていないと考 えられる. 山陽地域に分布する花崗岩由来の砂碴に 含まれる黒雲母などの鉄含有鉱物が地表で変質した ことにより，磁鉄鉱が生成した可能性もある ${ }^{21)}$ 。 た土壤中の新鮮な磁鉄鉱が地表近くに移動して, 1 年間变質していない可能性も考えられる.

我が国において森林褐色土が分布する雑木林での 鑑識や, 秘匿物の捜査を実施する場合, 平均気温や 降水量, 日照時間によって植生が異なり, 雑草が生 い茂るなど外観が変化するために, 目視では証拠品 が隠された場所を特定することが難しい場合が考え られる. 本研究のように, まずは簡易的に土畩表面 の初磁化率を測定し, このピークを見つけ出すこと 
で覺乱された場所を推定できる可能性がある。今 後, 広範囲での鑑識や捜査への応用するためには, 様々な種類の土壤での利用可能性についての検証が 必要であると考える。

\section{結 言}

広島県内の雑木林の森林褐色土に抢いて, 250 $\mathrm{cm}$ の観測線の一部分を攪乱させて, 土壤表面の初 磁化率を約 1 か月抢きに 1 年間測定した。 また観測 線の近くの場所から土壤の柱状試料を採取して, 初 磁化率や残留磁化強度, 磁気ヒステリシスの測定を 行った. 柱状試料と攪乱させた土壤表層試料の熱磁 気分析の結果からは，磁鉄鉱や赤鉄鉱が含まれてい ることが明らかになった．攪乱された場所やその近 傍は，1 年間にわたって初磁化率のピークとして認 められ, 強磁性鉱物の割合と粒径形, 主要元素の濃 度がこれら以外の場所と異なっていた. 事件や犯罪 の現場検証や鑑識などで, 攪乱された場所の特定が 目視では困難なとき, 簡易的に土壤表面の初磁化率 のピークからその場所を推定できる可能性がある.

\section{謝 辞}

産業技術総合研究所地質情報研究部門の森尻理恵 博士には, 磁化率計を貸していただいた。株式会社 リガクには携帯型 XRF を貸していただいた．本研 究は, 高知大学海洋コア総合研究センター全国共同 利用研究（採択番号19A0010, 19B008）の一部, 東 京大学大気海洋研究所共同利用研究 (受付番号 144 , 2018年）として行われた. 高知大学の山本裕二教授 には, 試料の低温磁気測定に便宜を図っていただい た. 科学研究費補助金（基盤研究 C, 20K01153）の 一部を使用して研究を実施した．以上の方々に厚く 御礼申し上げます。

\section{利益相反}

申告すべき利益相反はない.

\section{文 献}

1）杉田律子, 川村紀子, 組坂健人, 法地質学入 門. 地質学雑誌, 126, 407-410, 2020.

2) 組坂健人, 杉田律子, 日本の法地質学の歩
み. 地質学雑誌, 126, 425-431, 2020.

3）杉田律子, 法地質学における分析機器を用い た検査法の発展. 地質污染一医療地質一社会地 質学会誌, 11, 11-20, 2015.

4）杉田律子, 最近の法地質学の国際動向. 地質 学雑誌, 126, 433-442, 2020.

5）宮口一, 中原弘明, 杉田律子, 土壌中細胞 外DNAの抽出に抢ける市販キットの性能評 価. 日本法科学技術学会誌, 24, 63-72, 2019.

6) Ruffell A. and McKinley J., Forensic geoscience: applications of geology, geomorphology and geophysics to criminal investigations. EarthSci. Rev., 69, 235-247, 2005.

7) Ruffell A., Pringle J. K., Cassella J. P., Morgan R. M., Ferguson M., Heaton V. G., Hope C. and McKinley J. M., The use of geoscience methods for aquatic forensic searches. Earth-Sci. Rev., 171, 323-337, 2017.

8) Jordanova N., Soil Magnetism: Applications in Pedology, Environmental Science and Agriculture. Academic Press, San Diego, 2016.

9) Pringle J. K., Giubertoni M., Cassidy N. J., Wisniewski K. D., Hansen J. D., Linford N. T. and Daniels R. M., The use of magnetic susceptibility as a forensic search tool. Forensic Sci. Int., 246, 31-42, 2015.

10) Evans M. E. and Heller F., Environmental Magnetism: Principles and Applications of Enviromagnetics. Academic Press, San Diego, 2003.

11）川村紀子, 法地質学のッールとしての磁気測 定：レビュー。地質学雑誌, 126, 459-470, 2020.

12) Linford N. and Platzman E., Estimating the approximate firing temperature of burnt archaeological sediments through an unmixing algorithm applied to hysteresis data. Phys. Earth Planet. Interiors, 147, 197-207, 2004.

13）日本ペドロジー学会, 土壌調査ハンドブッ ク, 博友社, 東京, 1997.

14) Bloemendal., J., J. W. King, F. R. Hall and S.-J. Doh, Rock magnetism of late Neogene and 
Pleistocene deep-sea sediments: relationship to sediment source, diagenetic processes, and sediment lithology, J. Geophys. Res., 97, 4361-4375, 1992.

15) Maher B. A., Magnetic properties of some synthetic sub-micron magnetites. Geophys. J. 94, 8396. 1988.

16) Day R., Fuller M. and Schmidt V. A., Hysteresis properties of titanomagnetites: Grain-size and compositional dependence. Phys. Earth Planet. Inter., 13, 260-267, 1977.

17) Verwey E. J. W., Electron conduction of magnetite $\left(\mathrm{Fe}_{3} \mathrm{O}_{4}\right)$ and its transition point at low temperatures. Nature, 144, 327-328, 1939.

18) Özdemir Ö., Dunlop D. J. and Moskowitz B. M., The effect of oxidation on the Verwey transition in magnetite. Geophys. Res. Lett., 20, 16711674, 1993.
19) Raming T. P., Winnubst A. J. A., van Kats C. M. and Philipse A. P., The Synthesis and Magnetic Properties of Nanosized Hematite $\left(\alpha-\mathrm{Fe}_{2} \mathrm{O}_{3}\right)$ Particles. J. Colloid Interface Sci., 249, 346-350, 2002.

20) Wakabayashi K., Tsunakawa H., Mochizuki N., Yamamoto Y., and Takigami Y., Paleomagnetism of the middle Cretaceous Iritono granite in the Abukuma region, northeast Japan. Tectonophysics, 421, 161-171, 2006.

21）高木哲一, 磁鉄鉱系列/チタン鉄鉱系列花崗岩 質マグマの酸化還元状態の推移一中国地方中部 ～東部の例一，岩鉱， 88, 165-178, 1993.

22）気象庁ホームページ「各種データ・資料 各 地の気温, 降水量, 風など」: https://www.data. jma.go.jp/obd/stats/etrn/index.php（アクセス 日2019年12月). 